\title{
Active Tectonics and Geomorphology of the Kamchatsky Bay Coast in Kamchatka
}

\author{
T. K. Pinegina ${ }^{a}$, A. I. Kozhurin ${ }^{b}$, and V. V. Ponomareva ${ }^{a}$ \\ ${ }^{a}$ Institute of Volcanology and Seismology, Far East Branch, Russian Academy of Sciences, \\ bul'v Piipa 9, Petropavlovsk-Kamchatsky, 683006 Russia \\ e-mail: tsunami@kscnet.ru \\ ${ }^{b}$ Geological Institute, Russian Academy of Sciences, per. Pyzhevskii 7, Moscow, 119017 Russia \\ e-mail: kozhurin@ginras.ru \\ Received May 30, 2012
}

\begin{abstract}
Kamchatsky Bay is the northernmost bay at the Pacific Kamchatka coast. It is located at the junction between the Kamchatka segment of the Pacific subduction zone and the dextral transform fault of the western Aleutians. The combination of the subduction and collision processes in this region results in the unique set of tectonic controls influencing its geological and geomorphological evolution.

The Kamchatka River estuarine area is located on the northern coast of Kamchatsky Bay. The modern Kamchatka River valley, its estuary, and an aggradation marine terrace some $30 \mathrm{~km}$ long and up to $5 \mathrm{~km}$ wide were formed in this area during the Holocene. A vast area in the rear part of the terrace and in the Stolbovskaya lowlands is now occupied by the peats deposited directly above lacustrine-lagoonal and fluvial facies. These aggradational landforms record traces of tsunamis and vertical coseismic deformations associated with great subduction earthquakes, as well as strike-slip and thrust faulting associated with the collision.

The results indicate that the average recurrence interval for major tsunamis in the Kamchatsky Bay is 300 years. The recurrence interval on individual fault zones associated with the collision between the western Aleutian and Kamchatka arcs is a few thousand years for earthquakes of magnitude between 7 and 7.5. For the entire region, the recurrence interval for major crustal earthquakes associated with motions along faults may be equal to a few hundred years, which is comparable with that for subduction-zone earthquakes.
\end{abstract}

Keywords: subduction, arc-collision, active fault, tsunami, Holocene, Kamchatka River's lower reaches, marine terrace, Kamchatsky Bay

DOI: $10.1134 / \mathrm{S} 1819714014010047$

\section{INTRODUCTION}

Kamchatsky Bay is located at the junction between Kamchatka and the Aleutian island arcs. The Pacific Plate is plunging beneath Kamchatka at an approximate rate of $8 \mathrm{~cm} /$ year moving along a dextral transform fault of the Komandorsky segment of the Aleutian arc [20]. The edge of the Pacific Plate subducting under Kamchatka is now located along a transform fault zone of the western Aleutians, approximately beneath the southernmost part of the Kamchatsky Peninsula and near the present-day mouth of the Kamchatka River, and continues NW toward the Shiveluch Volcano (Fig. 1) [25, 32].

Different deformation styles are developed in the continental crust to the south and north of the subducting plate's edge $[8,29]$. In the suprasubduction zone, the deformation regime under Kamchatka is dominated by the oceanward extension [5] represented by systems of block-bounding listric normal faults and related monoclines dipping eastward toward the ocean [7]. The area north of the Pacific Plate margin is a collision zone where the western tip of the Aleutian arc converges against Kamchatka. The major structures here are represented by the western (beneath the eastern slope of the Kumroch Range) and eastern (in the Stolbovskaya Strait) collision contacts separated by the fault system of the Kamchatsky Bay Coast Peninsula [8]. From the surface geology and the plan-view geometry of the Quaternary sequences and structural zone, these two areas with different deformation regimes are separated from each other by a broad horizontal sinistral flexure (Fig. 1) [29].

Both the suprasubduction and collision-related deformation regimes in the earth's crust of Kamchatka are long-term processes (at least for the entire Quaternary) $[7,29]$, which govern the present geodynamics of the Kamchatsky Bay's coast. Meanwhile, the Kamchatka River is a demarcation between the active subduction zone to the south and the collision zone to the north. Thus, it is likely that manifestations of both subduction and collision processes might spatially overlap. The deformation processes occur in discrete pulses and are accompanied by large earthquakes.

The studied area is characterized by high seismicity $[2,11,24]$. The locations of the earthquakes are concentrated along the boundaries of the Pacific Platein the Kamchatka subduction zone within the Aleu- 


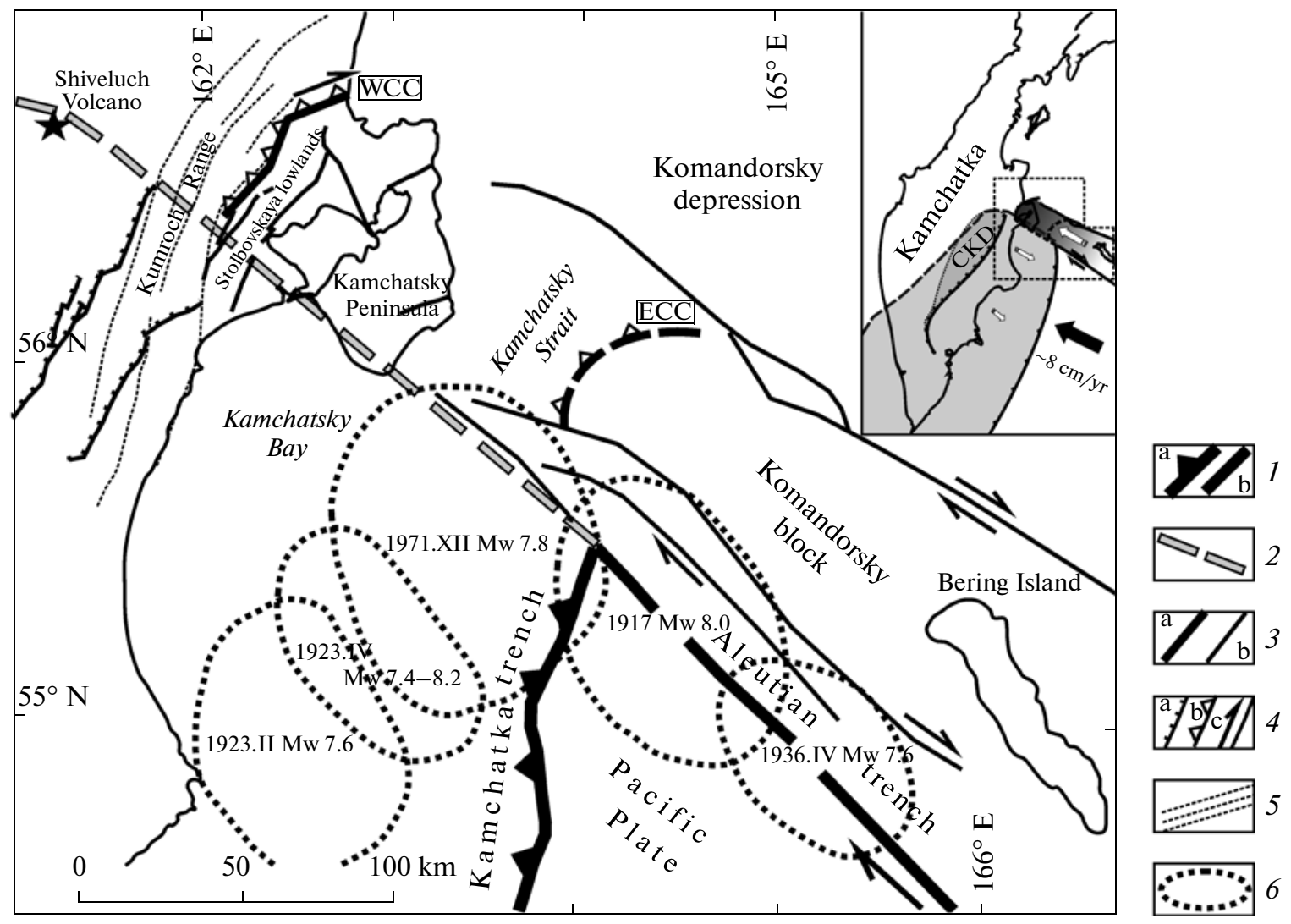

Fig. 1. Active structures at the Kamchatka-Aleutian arc junction.

(1) Pacific Plate boundaries [13, 14]: (a) subduction, (b) transform; (2) tentative position of the subducted edge of the Pacific Plate [25]; (3) active faults: (a) major, (b) other (including offshore faults [13, 14]; the inferred faults are shown by dashed lines); (4) fault kinematics: (a) normal faults, (b) thrusts and overthrusts, (c) strike-slip faults (the arrows show the direction of the downthrown (a) or upthrown (b) side); (5) strike of pre-Quaternary structures (sinistral horizontal flexure) [29]; (6) sources of major historical earthquakes (the numbers show the year, month, and magnitude of the earthquakes) [4]. WCC is the western collision contact [8], ECC is the eastern collision contact [23, 24]. The inset map shows the position of the subducted Pacific edge; the arrows show the direction of the relative motion of the Pacific Plate and the blocks of the Kamchatka and Aleutian arc and the motions along the Aleurtian transform fault. CKD is the Central Kamchatka depression.

tian strike-slip fault system and the parallel faults of the Komandorsky block. Earthquakes of magnitude between 7.5 and 8 were recorded in the studied area during the instrumental period. Two tsunamigenic earthquakes $(1923,1971)$ and a series of earthquakes of magnitudes greater than 7 occurred at the Aleutian-Kamchatka junction in the 20th century (Fig. 1) [4]. The seismicity in the Kamchatsky Peninsula and the neighboring region cannot be related to either of the two adjacent seismic zones $[11,26]$. In the peninsula, most earthquakes occur at depths shallower than $50 \mathrm{~km}$, whereas the main concentration of hypocenters of subduction-zone earthquakes is $20-30 \mathrm{~km}$ deeper in Kamchatsky Bay and farther along the Kamchatka trench. The crustal seismicity extends from the Kamchatsky Peninsula northwestward to the Kumroch Range. The presence of active faults and paleoearthquake traces in the peninsula $[8,12]$ testifies to the occurrence of larger magnitude events, which are meant to be crustal earthquakes with $M>6-6.5$ and subduction earthquakes with $M>8$, because such events are generally caused by large-amplitude movements along faults are often accompanied by fault and fold defomations expressed in topography. Such movements change the surface of the earth, thus governing the evolution of the surface relief and the geological structure of the region.

This study presents geological evidence for the occurrence of large Holocene seismic events (both crustal and subduction-zone) at the mouth of the Kamchatka River and examines their geologic and geomorphic effects.

\section{EFFECTS OF MOTIONS ALONG THE SUBDUCTION ZONE ON THE COASTAL MARGINS OF KAMCHATSKY BAY}

\section{Vertical Coseismic Deformations}

The results of geological studies, coupled with both on-land and satellite-based (GPS) geodetic measurements, show that the vertical coseismic deformations that accompany most large earthquakes in subduction 
zones are along coasts and thus located hundreds of kilometeres from deep-sea trenches (Fig. 2) [30]. Observations conducted after several major historical earthquakes (Chile, 1960, Mw = 9.5; Alaska, 1965, $\mathrm{Mw}=9.2 ;$ Indonesia, 2005, $\mathrm{Mw}=9.5$; Chile, 2010, $\mathrm{Mw}=8.8$; Japan $($ Tohoku), 2011, $\mathrm{Mw}=9.1$ ) showed that the movements during subduction-zone earthquakes are expressed as uplifting of the ground's surface above the shallower part of the source on the upthrown side of the fault or as the subsidence of the ground's surface above the deeper part of the source located close to a volcanic arc. Such observations are valid also for the $M<8$ earthquakes, whereas vertical motions with small amplitudes at large distances from earthquake sources can only be recorded instrumentally. The amplitudes of the coseismic coastal subsidence during major earthquakes may reach a few meters, thus causing erosion in some parts of the coast and changing the active beach profile.

A distinctive feature of the coastline segment of interest is its proximity to the northern tip of the Kamchatka subduction zone, i.e., to the northern edge of the subducting Pacific Plate. Thus, the questions are, How big is the seismic potential at the edge of the subduction zone and what are the amplitudes of the vertical coseismic displacement along the coast. The answer to this question is hindered by a paucity of reliable geological data. Two scenarios are most likely.

(1) Deformations during subduction-zone earthquakes across the coastal region of Kamchatsky Bay near the edge of the Pacific Plate are found to be the same (in terms of their type and intensity) as those along the coast of eastern Kamchatka at some distance from the plate's edge: interseismic uplift; coseismic and, most probably, postseismic subsidence during the seismic cycle. These motions can result in repeated subsidence and erosion of the marine aggradation terraces followed by uplifting and seaward progradation.

The resulting (permanent) vertical deformations accumulated throughout several seismic cycles can be small or equal to zero.

(2) The rate and maximum amount of elastic strain build up vary along the Kamchatka subduction zone and decrease significantly at its northern tip near the edge of the subducting plate. In that case, the vertical coseismic deformations would be zero along the coast of Kamchatsky Bay. This inference is supported by the fact that the northern segment of the Kamchatka subduction zone lacks catastrophic earthquakes such as the 1737 and $1952 \mathrm{Mw} \sim 9$ Kamchatka multisegment earthquakes over the period of instrumental observations [4]. However, due to the absence of a resident population in the coastal regions of Kamchatsky Bay and the quality of the historical earthquake data, the lack of such earthquakes cannot be stated with $100 \%$ certainty.

It was found that the sea level stabilized between 5.5 and $6.5 \mathrm{kyr}$ BP (mid-Holocene) [15, 16, 21]. This

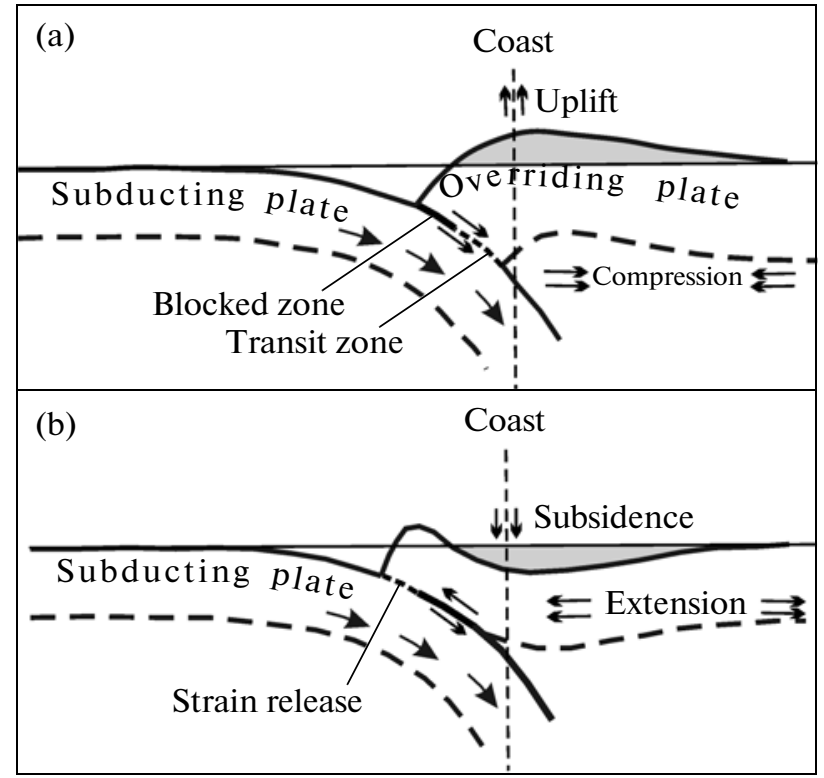

Fig. 2. Simplified deformation model for the lithospheric plate subduction zone [30].

(A) interseismic elastic strain accumulation phase; (B) coseismic phase of strain release through fault slip.

implies that the Holocene marine terraces that formed over the past $\sim 6$ kyr may have been preserved on stable and uplifting coasts. However, the oldest Holocene marine terraces preserved on the coast of Kamchatsky Bay are no older than $1.5-3$ ka $[12,17]$. For example, the oldest beach ridge preserved in northwestern Kamchatsky Bay formed about $3 \mathrm{ka}$ [12]. At the same time, the age of the peat beds overlying lagoonal deposits behind this beach ridge is about $6 \mathrm{ka}$ [9]. This suggests that the beach ridges formed between 3 and 6 ka were eroded (all the dates are calibrated ${ }^{14} \mathrm{C}$ ages) due to major coastal subsidence. The presence of relatively thick loam layers (e.g., in the Cherny Yar section [9]) in the peat beds located some 5-10 km away from the present-day coastline provides compelling evidence for coseismic costal subsidence.

\section{Reconstruction of the Great Earthquake Recurrence at Subduction Zones Based on Tsunami Deposits}

Historical records indicate that the sources of major tsunamis that affected the estuarine area of the Kamchatka River and the Ust'-Kamchatsky settlement were located within the northern segment of the Kamchatka subduction zone. Tsunamis from local sources in eastern and southeastern Kamchatka and in the Bering Sea, as well as distant-source tsunamis (e.g., arriving from South America) reported in the vicinity of the Ust'-Kamchatsky village were not very intensive (runups $<5 \mathrm{~m}$ ) [6]. The probability of generating a large tsunami from earthquake sources along transform boundaries of the Komandorsky block is a question to which there is still no unambiguous 
Table 1. Data on the historical and prehistorical tsunamis in northern Kamchatsky Bay

\begin{tabular}{c|c|c|c}
\hline Nos. & Age & $\begin{array}{c}\text { Minimum } \\
\text { runup } \\
\text { height, } \mathrm{m}\end{array}$ & $\begin{array}{c}\text { Minimum } \\
\text { inundation } \\
\text { distance, } \mathrm{m}\end{array}$ \\
\hline 1 & $1923^{*}$ & $>6$ & $>1800 \mathrm{~m}$ \\
2 & $1737^{*}$ & $>8$ & $>1600 \mathrm{~m}$ \\
3 & $550 \pm 250$ & $>6$ & $>500 \mathrm{~m}$ \\
4 & $1075 \pm 275$ & $>4.5$ & $>600 \mathrm{~m}$ \\
5 & $1425 \pm 75$ & $>4$ & $>250 \mathrm{~m}$ \\
6 & $1575 \pm 75$ & $>4$ & $>200 \mathrm{~m}$ \\
7 & $1775 \pm 125$ & $>7$ & $>300 \mathrm{~m}$ \\
8 & $2200 \pm 300$ & $>8$ & $>500 \mathrm{~m}$ \\
\hline
\end{tabular}

* The ages of the historical tsunamis events are indicated in years $\mathrm{AD}$; the ages of the remaining tsunamis events are indicated in years before AD 1950.

answer, because this does not seem to have happened in historical times. This is also supported by our data collected on tsunami deposits from Bering Island. Two local earthquakes accompanied by small tsunamis (December 15, 1971, $M=7.8$; December 28, 1984, $M=7.5$ ) have been recorded in Kamchatsky Bay over the instrumental period as indicated by the seismological observations since 1962. Based on the historical macroseismic data, earthquakes in the region were felt in 1737 (probably accompanied by a large tsunamis), 1791, 1792 (probably tsunamis?), 1807, 1923 (a devastating tsunami), and 1936 (probably a small tsunami) $[1,6]$. Small tsunamis from Kamchatka and more distant sources were recorded in the vicinity of Ust'Kamchatsky in 1952, 1960, 1969, 2001, and 2010 [38].

Historical records do not reveal whether the 1737 earthquake was accompanied by a tsunami in Kamchatsky Bay. Since the coast was largely an unpopulated area at that time, no human records are available. At the same time, the macroseismic parameters of the November 4, 1737 earthquake, which were derived from a description of earthquake damage to the Nizhnekamchatsk settlement located $30 \mathrm{~km}$ landward of the coast [1], suggest that this tsunami was more likely to have occurred. It can be correlated with the layer of tsunami deposit directly below the 1923 tsunami deposit. The tsunami event of August 22, 1792 is also mentioned in the literature [1]. However, the description of this event was interpreted as doubtful [12]. The existence of only one prehistoric tsunami deposit directly below the 1923 tsunami deposit in the section accumulated over the last 300 years suggests that a large tsunami in the region occurred in 1737 but not in 1792. It was similar in intensity to the 1923 event (Table 1).

The methods used to investigate the tsunami deposits were previously described in detail elsewhere $[10,16,34,35]$; therefore, we will not discuss them here. It should be pointed out that the position of the paleocoastline and the elevation of the marine terrace relative to the sea level at the time of the tsunami events were taken into account in the calculations of the paleotsunami parameters [12].

The eight layers of paleotsunami deposits over the last $\sim 2500$ years were identified in sampling pits excavated on the surface of the marine terrace on the right bank near the mouth of the Kamchatka River. The main parameters of these events are given in Table 1. The ages and uncertainties of the estimated event ages were calculated from the radiocarbon ages obtained elsewhere for the volcanic ash layers above and below the layers of the tsunami deposits $[11,12,16]$ (Table 2).

The data on the prehistoric tsunami inundation distances and runup heights shown in Table 1 can be significantly underestimated because of the following:

(1) these estimates are based on the height of the highest beach ridges overflowed by the tsunami waves;

(2) the accuracy of the reconstructed coastline's position at the time of the tsunami event depends on the resolution of the tephrochonology (the amount of the identified ashes in the studied area and the accuracy of their ${ }^{14} \mathrm{C}$ ages). At the same time, all of the reported tsunamis are interpreted to be strong enough. For example, the 1960 Chilean tsunami did not leave extensive deposits all along the coast because its maximum inundation distance was less than the storm surge, although the wave heights reached 2-4 $\mathrm{m}$ along the coast of Kamchatsky Bay [6].

The paleoseismological results indicate that large tsunamis have occurred about once every 312 years on the average around Kamchatsky Bay over the last 2500 years. The recurrence interval for paleotsunamis probably corresponds to that of large earthquakes $(M$ $\geq 8$ ) in the northern edge of the Kamchatka subduction zone. Smaller seismic events occur more frequently here. It should be noted that the temporal distribution of earthquakes and tsunamis is not linear (i.e., given the average return period of 300 years); some events occur very close in time, while some are separated by large gaps. Therefore, it can be concluded that the northern edge of the Kamchatka subduction zone is capable of generating earthquakes of magnitude about 8 . However, the probability of generating earthquakes of magnitude about 9 cannot be defined exactly.

\section{IMPACT OF COLLISION-RELATED DEFORMATIONS WITHIN THE KAMCHATSKY PENINSULA ON THE KAMCHATSKY BAY COAST}

The Kamchatsky Peninsula, together with the Stolbovskaya lowlands in the west and the Kamchatka River estuarine area, is intensely faulted [8, 22, 23, 27, 28]. In this area, the kinematics of the faults (thrust 
Table 2. Holocene tephra markers used for dating deposits from the Kamchatka River estuarine area**

\begin{tabular}{l|l|c|c|l|c}
\hline $\begin{array}{c}\text { Tephra } \\
\text { index }\end{array}$ & \multicolumn{1}{|c|}{$\begin{array}{c}\text { Tephra } \\
\text { source }\end{array}$} & $\begin{array}{c}\text { Mean }{ }^{14} \mathrm{C} \text { age } \\
\left({ }^{14} \mathrm{C} \text { yr before }\right. \\
\text { AD 1950) }\end{array}$ & $\begin{array}{c}\text { Rounded age } \\
\text { (years before AD 1950 } \\
\text { or years AD (1) } \\
\text { for historical earthquakes) }\end{array}$ & Ash description & $\begin{array}{c}\text { Thickness range } \\
\text { in different sec- } \\
\text { tions (cm) }\end{array}$ \\
\hline $\mathrm{SH}_{1964}$ & Shiveluch & Historical & $1964^{(1)}$ & Pepper-and-salt mg-cg sand & $0.5-4$ \\
$\mathrm{KL}$ & Klyuchevskoy & Historical & $1878^{(1)}$ ? & Black fg-vfg sand & $0.5-1$ \\
$\mathrm{SH}_{1}$ & Shiveluch & $265 \pm 16$ & 300 & Pale fg-vfg sand & $0.5-2$ \\
$\mathrm{SH}_{2}$ & Shiveluch & $965 \pm 16$ & 800 & Pale fg-vfg sand & $1-2$ \\
$\mathrm{SH}_{1450}$ & Shiveluch & 1450 & 1350 & Pepper-and-salt fg-mg sand & $1-3(5)$ \\
$\mathrm{SH}$ & Shiveluch & - & 1500 & Pale fg-vfg sand & $0.5-2$ \\
$\mathrm{KS}_{1}$ & Ksudach & $1806 \pm 16$ & 1650 & Pale yellow vfg-fg sand & $5-7$ \\
$\mathrm{SH}$ & Shiveluch & - & 1900 & Pepper-and-salt mg sand & $1-2$ \\
$\mathrm{SH}_{5}$ & Shiveluch & $2553 \pm 46$ & 2500 & Pepper-and-salt fg sand & $1-2$ \\
$\mathrm{SH}_{2800}$ & Shiveluch & 2800 & 3000 & Pepper-and-salt mg sand & $1-3$ \\
$\mathrm{SH}_{s p}$ & Shiveluch & 3600 & 3950 & Dark grey fg-mg sand & $1-2$ \\
$\mathrm{SHdv}$ & Shiveluch & $4105 \pm 31$ & 4700 & Pale yellow vfg sand & $3-5$ \\
$\mathrm{SH}_{4800}$ & Shiveluch & 4800 & 5600 & Pepper-and-salt fg-mg sand & $2-3$ \\
$\mathrm{AB}_{4}$ & Avacha & $5489 \pm 27$ & 6150 & Pale yellow vfg sand & 0.5 \\
\hline
\end{tabular}

** The radiocarbon ages and tephra marker indices are after $[9,18]$. The blank in column 3 indicates that the mean radiocarbon age was not calculated. The radiocarbon ages were calibrated using the Calib 6.0 program $[19,36]$ and rounded to the nearest fifty years. mg, medium-grained; cg, coarse-grained; fg, fine-grained; vfg, very-fine-grained..

faults, overthrusts, and strike-slip faults) clearly indicate an E-W compression, while the distribution of the faults and fault zone structures indicates a convergence between the peninsula block and Kamchatka and its thrusting under the Kumroch range (Fig. 1, 3). The field observation of the structures [7, 8, 12, 28] demonstrates that the faults do not creep but instead move in pulses, which is accompanied by large earthquakes with $\mathrm{Mw} \geq 5.5-6$. The difference between aseismic pulselike motions, which have been recently reported in the literature [30], and seismogenic motions is that the former are related to secondary ruptures and are accompanied by earthquakes with $\mathrm{Mw} \leq$ 5.5. Since such secondary ruptures were not identified along the Kamchatsky Bay coast, we focus in this study mostly on the major active faults. Due to the cumulative vertical displacements generated by individual motions, the major active faults are clearly visible in the Late Pleistocene and Holocene topography as fault scarps ranging in height from a few to a few tens of meters. Fault scarps are the major controls of the distribution of the present-day drainage patterns and the deposition and erosion of soft sediments.

One of the best-studied active faults in the region is the Ust'-Kamchatsky fault [12]. It crosses the Kamchatka River at the Cherny Yar locality and intersects the flat swampy surface of the Stolbovskaya lowlands to the north and partly the beach ridges on the marine terrace to the south (Fig. 3). This fault has a NNE trend and an azimuth ranging from $15^{\circ}$ in the south to $25-30^{\circ}$ in the north. It has a visible length of $20-25 \mathrm{~km}$ (minimum estimate) and extends offshore into Kamchatsky Bay. The fault is topographically expressed as a fault scarp downthrown on the southeastern side. The height of the young (Holocene) fault scarp is $2-4 \mathrm{~m}$ on average. There were three or four movements along the Ust'-Kamchatsky fault over the last $~ 5800$ years: $5800-$ $5600, \sim 4700$, and 300-800 years ago in the north and 1700 years ago in the south in the vicinity of beach ridges [12]. If we exclude from consideration the $\sim 4700$ year old event, which can be attributed to movement on the adjacent fault (as inferred from liquefaction), the average recurrence interval for movements along the entire fault is $2-2.5 \mathrm{ka}$. Based on the empirical relationships between the length, the average amount of movement, and the magnitude [31, 37], a fault with a length of $20 \mathrm{~km}$ and an average net slip displacement of $1.5 \mathrm{~m}$ per event can generate an earthquake with $\mathrm{M}=6.7-6.8$

It should be taken into account that the above values are minimum estimates of the length and amount of a single-event displacement along the Ust'-Kamchatsky fault (we determined only the vertical component of the displacement, while accurate strike-slip measurements were impossible). The earthquake magnitude can evidently be higher than the above estimate and may reach a value of 7.5. Field measurements of single-event net slip displacements at other 


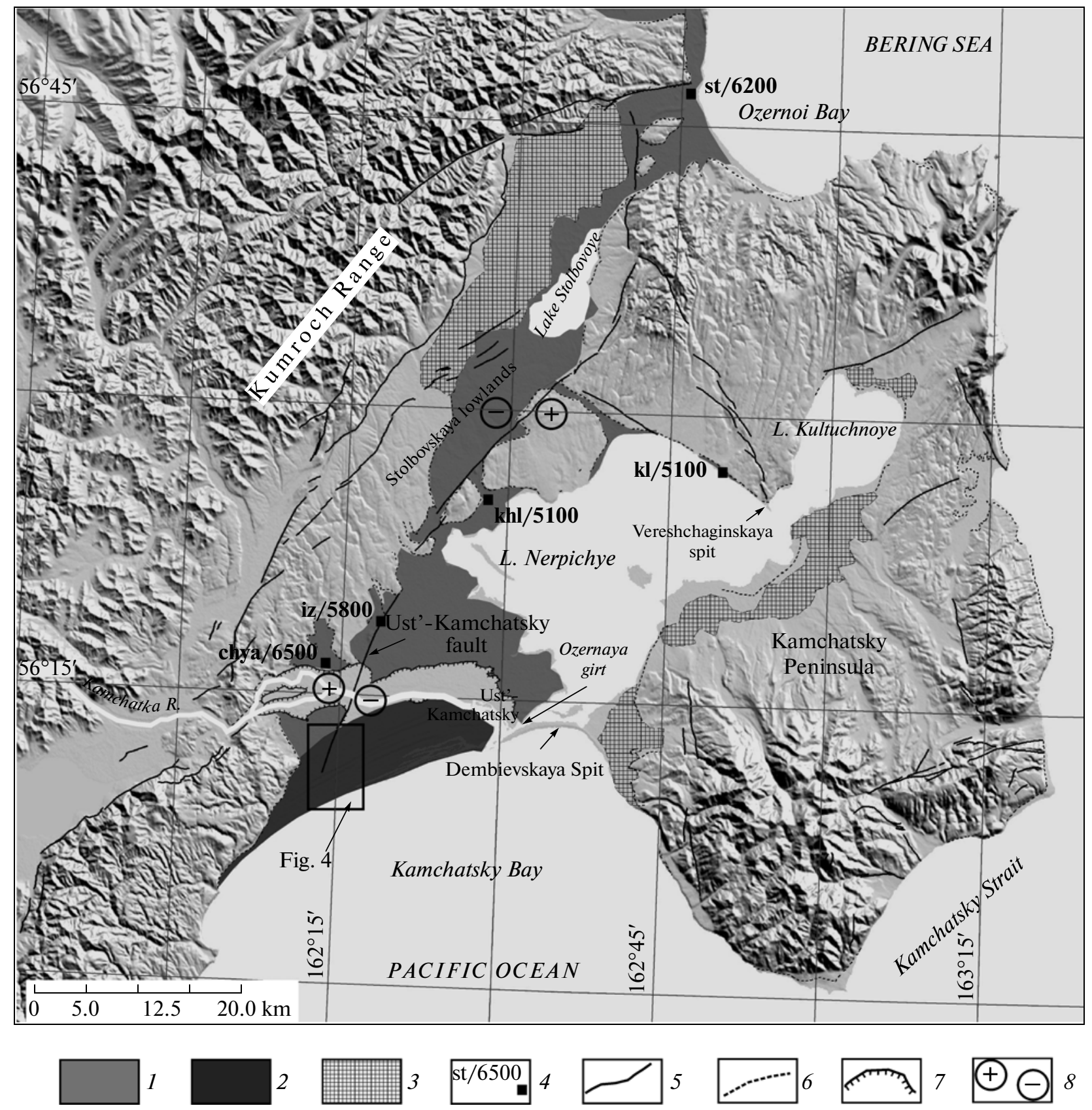

Fig. 3. Geomorphologic scheme showing the Kamchatka River estuarine area and the surrounding area.

(1) Holocene peats; (2) Holocene marine aggradation terrace on the right bank of the Kamchatka River; (4) Late PleistoceneHolocene proluvial-alluvial fans; (4) age of the basal pest deposit (years before AD 1950). The letters denote the key sections: chya-Cherny Yar, iz-Izvilisty, khl-Khalnitsa, Kl-Kultuk, st-Stolbovskaya; (6) active faults; (7) paleosea cliff corresponding to the Holocene sea level's high standing (ca. $6.5 \mathrm{ka}$ ); $(8)$ boundaries of the Kamchatka River valley in its lower reaches; (9) upthrown $(+)$ and downthrown $(-)$ side of the active faults.

sites within the Stolbovskaya lowlands [8] show that all the active fault in the region are characterized by an almost similar $M_{\max }$. Assuming a comparable recurrence interval for the motions along all the active faults in the region with the same geodynamic situation, we determined that a large crustal earthquake in the region occurs every few hundred years.

\section{HOLOCENE GEOLOGY AND GEOMORPHOLOGICAL EVOLUTION OF THE KAMCHATKA RIVER ESTUARINE AREA}

The Kamchatka River estuarine area includes its estuary, its lower reaches, and the coastal area of Kamchatsky Bay with a radius of about $10 \mathrm{~km}$ from the river 
mouth. The river estuary includes two lakes (the Nerpichye and Kultuchnoye), the Ozernaya girt, and a lagoon system located on a marine terrace. The lower reaches of the river flow through the Stolbovskaya lowlands from the Cherny Yar locality to the estuarine section's line (Fig. 1, 3). Below, we discuss the key events that have affected the present-day coastal features of Kamchatsky Bay and the Kamchatka River estuarine area as a result of active tectonic environment. The main geomorphic features of the region include a marine aggaradation terrace located on the right bank of Kamchatsky Bay, the Stolbovskaya lowlands with widespread peat accumulation, the Kamchatka River valley with a series of fluvial terraces, and two lakes (the Nerpichye and Kultuchnoye) with lake terraces.

\section{Marine Aggradation Terrace on the Right Bank of the Kamchatka River}

A marine aggradation terrace some $5 \mathrm{~km}$ wide and up to $30 \mathrm{~km}$ long is located on the right bank of the Kamchatka River close to its mouth. To understand the history of the marine terrace's formation, a topographic transect was measured from the water line normal to the strike of the beach ridges. Samples collected from pits along the transect's line were used for the detailed description of the sections (Figs. 3, 4).

The tentative age of the beach ridges at the time when they ceased to be active was determined from the known ages of the oldest of the overlying volcanic ash beds (Table 2). These data [12] were used to tentatively determine the position of the coastline at different times and reconstruct the history of the marine terrace formation (Fig. 4).

The width of the present active beach with a distinct lack of surface soil layers and volcanic ash deposits is about $200 \mathrm{~m}$. The thickness of the soil-pyroclastic cover pyroclastic in all the sections is not greater than $50 \mathrm{~cm}$. The oldest known beach ridge was formed shortly before the $\mathrm{SH}_{2800}$ ash-fall event ( $\sim 3000$ years ago). The analysis of the coastline segment along the topographic profile (with well-preserved original landforms) shows that the coast was uplifted about $2.5 \mathrm{~m}$ during the past 1500 years (between two Shiveluch ash-fall events, $1500 \mathrm{yr}$ ago and in 1964). The average coastal uplift rate for this time is $1.5 \mathrm{~mm} / \mathrm{yr}$, and the coastal progradation rate is $0.8-0.9 \mathrm{~m} / \mathrm{yr}$.

Figure 4 shows the coastline position's change at different times in the past. If we pick small time intervals (between the closest volcanic ash layers), then the seaward progradation rate of the terrace varied significantly with time. For example, it was at least 4 times greater during the interval of 1350-1650 yr ago than during $800-1350 \mathrm{yr}$ ago. This can be explained by the partial erosion of the terrace during some intervals of time. If we assume that the amount of terrigenous supply to the Kamchatsky Bay coast was nearly constant during the Middle-Late Holocene, then such erosion of the terrace could be associated with the coseismic coastal subsidence during the great subduction earthquakes.

The topographic profile across the terrace is gently inclined seaward (the older bars are located at a hypsometrically higher level). This indicates an overall costal uplift during the formation of the marine terrace. A more detailed consideration reveals several knickpoints in the topographic profile, one of which is located at test pit 27 (Fig. 4). A segment of the profile with gentle slopes, which is located seaward of test pit 27 to test pit 17, can be extrapolated as a straight line, suggesting that it was formed during a period when the relative sea-level was constant. Of particular interest is the profile segment from test pit 17 and farther seawards. It can be seen that the beach ridge containing the SH1964 tephra layer is about $1 \mathrm{~m}$ higher than the adjacent older bar, which contains the Klyuchevskoy tephra layer (from the $\sim 1878$ ash-fall event) at the base of the soil cover. This difference in height of the beach ridges of almost similar age may be related to a smaller amplitude coseismic coastal subsidence during the strong historical earthquake of April 14, 1923. The retrospective seismological observations show that the magnitude of this earthquake (Mw) was 7.4-8.2 [4]. If it is assumed that coseismic coastal subsidence really occurred during this earthquake, then the upper limit of the magnitude range seems to be more realistic.

It should be noted that the difference in the height of the beach ridges formed before and after the seismic event rarely corresponds to the actual amplitude of the vertical coseismic deformation. This discrepancy is caused by the temporal postseismic changes in the magnitude of the wave energy and the offshore beach profile, as well as the partial erosion of the beach and sometimes of the beach ridges of different ages formed before the seismic event. It is impossible to determine from the paleoreconstruction whether the erosion stopped at the top of an ancient beach ridge or on its backslope.

\section{STOLBOVSKAYA LOWLANDS}

The Stolbovskaya lowlands are located east of the Kumroch Range and extend NNE for $60 \mathrm{~km}$ with an average width of $10 \mathrm{~km}$. The bottom of the lowlands is covered by peat deposits up to 2-4 m thick [12]. The basal grey loams and fine sands, which lack clear bedding, are interpreted as lacustrine and lagoon deposits $[12,16]$. A vast but shallow body of water that once occupied the present Stolbovskaya lowlands started to get vegetation cover 6500-5100 years ago, i.e., during the Holocene highstand. Peat accumulation on the upthrown sides of active faults began earlier than on the downthrown sides. For example, the Cherny Yar peats [9] is 1-1.5 ka older than the adjacent peat deposits previously described by Bourgeois et al. [16] 
(a)

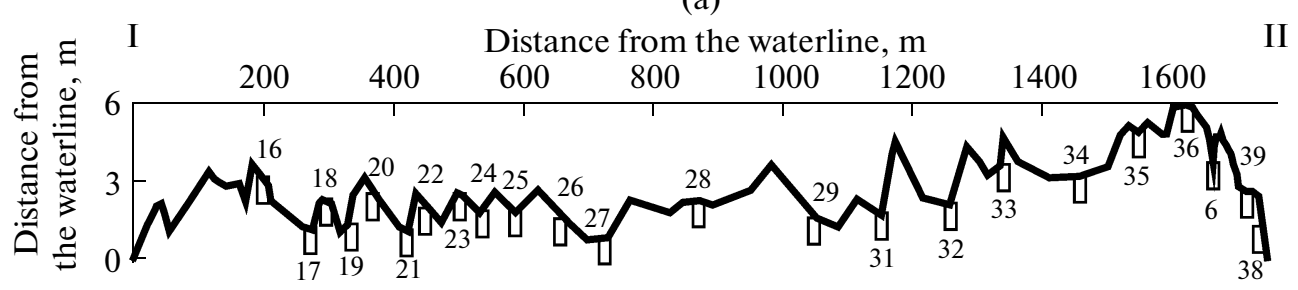

(b)
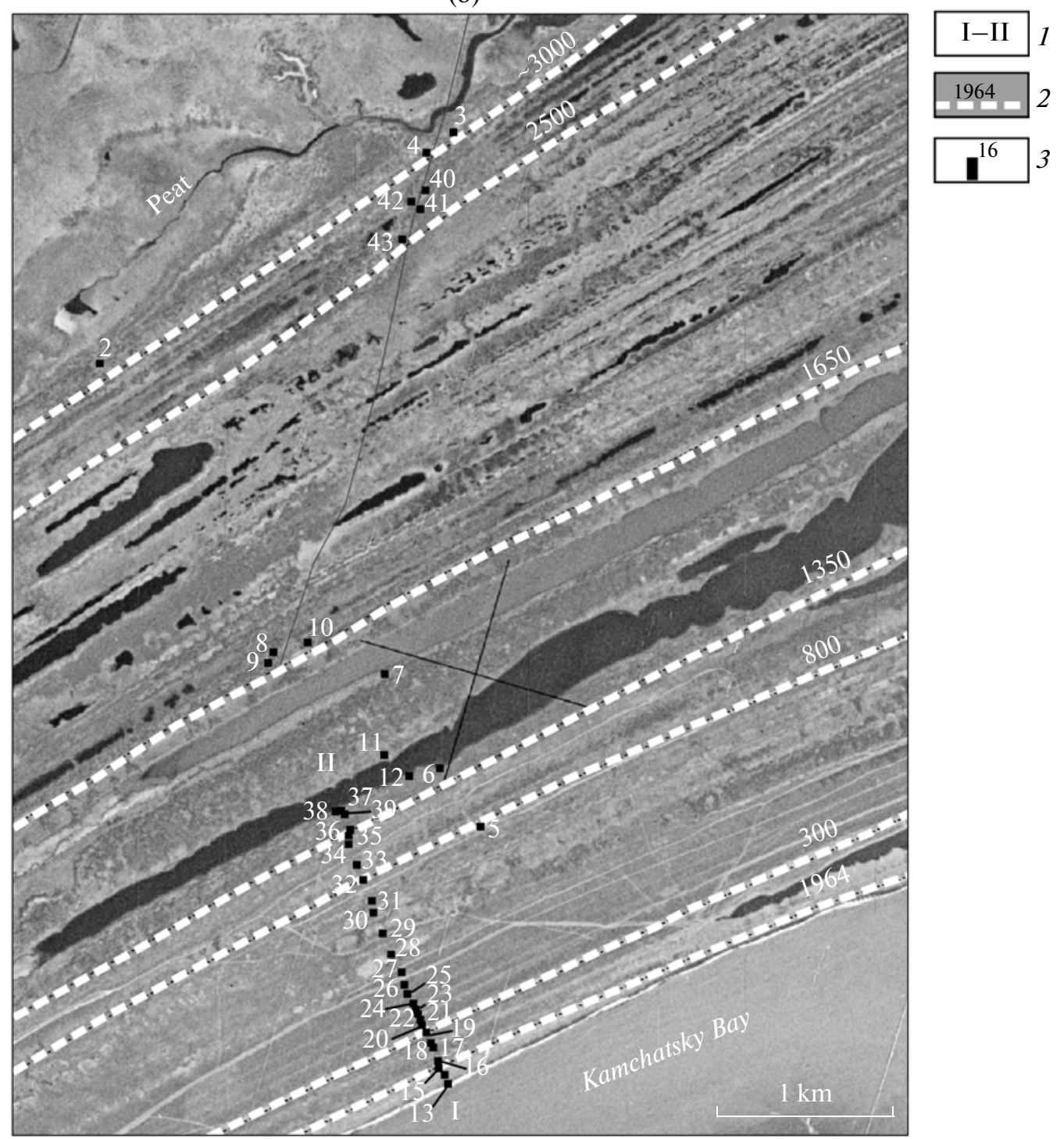

Fig. 4. The results of the survey across the marine aggradation terrace.

(a) topographic profile i-ii measured across the strike of the beach ridges; (b) fragment of an aerial photograph showing the location and numbers of the sampling pits: (1) location of the topographic profile across the marine terrace; (2) location of the upper active beach boundary at different times (years before AD 1950 for all the boundaries older than 1964 AD); (3) location and numbers of the sampling pits excavated along topographic profile I-II.

because it was deposited on the upthrown side of the Ust'-Kamchatsky fault (Fig. 3).

During the Holocene sea-level highstand, this body of shallow water was likely separated from the open sea by a system of beach ridges and the fine sed- imentation and overgrowth raised the bottom of the lake water in the absence of wave action. A large amount of sediments was transported to the shallow waters by the Kamchatka River and other inflowing streams, while the other sediment sources were debris 
cones and alluvial fans on slopes of the Kumroch Range (Fig. 3). The ancient beach ridges separating this shallow body of water from the open sea were preserved in part in the northeastern part of the Stolbovskaya lowlands [16] and were completely destroyed in its southwestern part.

The interpretation of the aerial photographs and KH-9 satellite imagery (about $4.7 \mathrm{~m}$ per pixel) revealed the position of the oldest paleosea cliff, which reflects the Holocene sea level's high stand (Fig. 3). This cliff bordering the Stolbovskaya lowlands in the west is interpreted to be transitional to marine in its southernmost tip, where it adjoins the marine terrace. The remaining part of the cliff that surrounds the shallow lake is of lacustrine-lagoonal origin. The distinct topographic expression of this cliff formed under isolated and low wave-energy conditions can be explained by its inheritance from the spatially coincident abrasion scarp, which formed at 120-130 ka (MIS 5e) when the sea-level was approximately the same or slightly higher than at present [33]. During that time, the entire area of the Stolbovskaya lowlands may have been occupied by a sea passage separating the mountain ranges of Kamchatsky peninsula from the Kumroch Range. Since the Holocene marine terraces and the deposits of the Stolbovskaya lowlands are absent, a shallow lake or lagoon occupied the former sea passage during the Holocene.

Lake Stolbovoye, some $11 \mathrm{~km}$ in length and up to $5 \mathrm{~km}$ in width, is a remnant of the much larger body of shallow water that occupied the entire area of the Stolbovskaya lowlands. The present-day lake has a maximum depth of $4 \mathrm{~m}$ and an average depth of 2-3 m (Fig. 5). Today, the lake is rapidly decreasing in area due to it being overgrown. The ground-penetrating radar (GPR) data show that the lake has a flat, nearly horizontal bottom and the thickness of the bottom deposits is up to $4 \mathrm{~m}$. The signal's attenuation with depth may be indicative of loam deposits, which significantly reduce the depth of penetration of the radar signal.

The active faults (Fig. 3) within the Stolbovskaya lowlands have a significant effect on the lowlands morphology, the groundwater level, the hydrological regime, and the peat accumulation rate. The height of the fault scarps visible in the Late PleistoceneHolocene topography ranges from one meter to a few tens of meters; the recurrence interval on individual fault zones is a few thousand years and a few hundred years for all the fault zones [8, 27, 28].

\section{Kamchatka River Valley in the Estuary Area}

The sea level was approximately $120 \mathrm{~m}$ lower than at present during the Late Pleistocene-Early Holocene [21], and the estuarine area of the Kamchatka River occupied the place of the present-day continental shelf in Kamchatsky Bay. Smaller topo- graphic lows that occupied the area of the present-day Lakes Nerpichye and Kultuchnoye and the Stolbovskaya lowlands were filled with glacial, fluvioglacial, and alluvial deposits. This is supported by the fact that the present topography from the Kumroch Range to the western slopes of the Kamchatsky Peninsula mountain ranges is mantled by Early Late Pleistocene deposits $\left(\mathrm{Q}_{\mathrm{I}}, \mathrm{Q}_{\mathrm{III}}^{2}\right)$ [3]. A new Holocene river valley that once occupied the Kamchatka River estuarine area was formed during the mid-Holocene, when the sea level was similar to the present level. The boundaries of this new valley were delineated from the interpretation of the aerial photography and satellite imagery data (Fig. 3). All the fluvial terraces in the lower reaches are contained in Middle Holocene peats; i.e., they are Middle-Late Holocene in age. The meandering river erodes its terraces so that the low and hight floodplains appear to be the most extensive. The river undercuts the backslope of the marine terrace and erodes the $2-3$ ka beach ridges, which provides additional evidence for younger ages of the fluvial terraces. After the onset of peat formation in the Stolbovskaya lowlands, the channel boundaries of the Kamchatka River remained unchanged and were confined to the same valley identified on aerial photographs so that flooding of the adjacent peat-plain was unlikely. This is supported by the absence of pronounced river landforms within the Stolbovskaya lowlands surface relief (except for streams not connected with the Kamchatka River) and channel deposits with characteristic cross stratification below the basal peat. The fine sands and loams found at the base of the peat are unlikely to be floodplain deposits due to the lack of rhythmicity and stratification (alternating coarser and finer layers), which is typical of the floodplain facies. We can assume that the flooding of peat deposits adjacent to the Kamchatka River valley occurred only locally and was restricted to a narrow zone along the channel, as indicated by several loam beds of unclear origin found in the section of the Cherny Yar peat deposit [9]. These beds might be the result of catastrophic tsunamis and/or coseismic coastal subsidence.

\section{Lakes Nerpichye and Kultuchnoye}

Lakes Nerpichye and Kultuchnoye occupy a relict depression in the central part of the Kamchatsky Peninsula formed as a result of the Quaternary uplifting of the peninsula's margins. The lakes extend in the NESW direction for a total distance of over $40 \mathrm{~km}$ and have a total perimeter of about $130 \mathrm{~km}$. The Pleistocene marine and Holocene lake terraces are developed along the present-day shoreline of these lakes. In the mid-Holocene, the lakes were probably connected to a shallow water body that occupied the area of the Stolbovskaya lowlands.

Several lake terraces with ages between $\sim 2000$ and $1500 \mathrm{yr}$ (dated by tephrochronology, Table 2) are well 
(a)
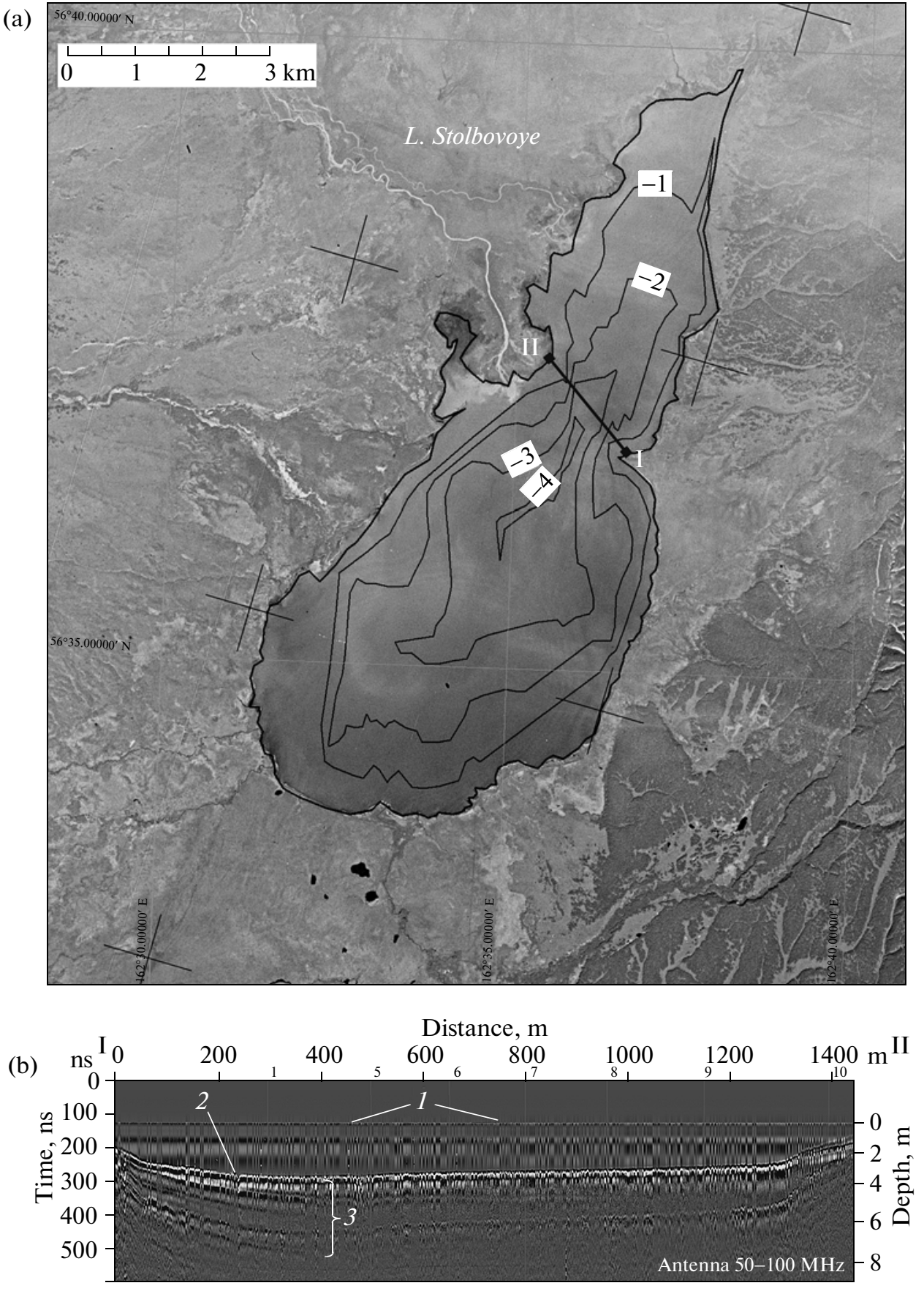

Fig. 5. The structure of Lake Stolbovoye.

(a) bathymetric map based on the echo-sounding results; (b) GPR profile through the I-II line: (1) the water's surface, (2) the bottom's surface, (3) the subhorizontal strata of the lake deposits.

preserved along the coast of the lakes. A younger terrace formed about $200-300 \mathrm{yr}$ ago is poorly preserved. Remnants of the oldest lake terrace with an age of $5000-6000 \mathrm{yr}$ are preserved only at the base of the Vereshchaginskaya sand spit, which separates Lakes Nerpichye and Kultuchnoye. This Middle Holocene terrace has been eroded over much of the coast, which suggests the resulting subsidence.
Measurements revealed that shoreline angles of lake terraces of the same age are present at various elevations above the present lake levels. This is also true for the younger lake terraces formed a few thousand or hundred years ago. Because, the height of the shoreline angles of the individual lake terraces should be approximately the same along their length, the difference in elevation is probably a reflection of the non- 
uniform deformation pattern on the opposite flanks of the central depression occupied by lakes.

The rates of the vertical deformation along the coast of these lakes are less variable than those of the eastern (marine) coast of the peninsula [11], which is indicative of significant variations in the deformation intensity in different parts of the peninsula. The measurements of the 2 ka lake terrace show that the average uplift rate along the coastline of these lakes ranges from $\sim 0.3$ to $1.6 \mathrm{~mm} /$ year, whereas the uplift rates estimated for the 2 ka marine terrace in eastern Kamchatsky peninsula average about $7 \mathrm{~mm} /$ year [11].

Both slow and fast (coseismic) deformations within the peninsula could have directly affected the tidal regime in Kamchatsky Bay as well as the lake salinity. The width of the Ozernaya River may have varied in the past. The measurements showed that the Dembievskaya spit, which separates the river from the marine coast, is not older than 1000 years in its oldest (northeastern) segment. The Dembievskaya spit is a highly dynamic feature, and changes in its position, width, and length may happen very fast (due to the combined action of the Kamchatka River and the sea) and even abruptly (in the case of large earthquakes and tsunamis). This may produce significant variations in the lake salinity (in particular, the seaward part of Lake Nerpichye), the water regime, and the deposition environments.

\section{CONCLUSIONS}

The Pleistocene and Holocene evolution of the Kamchatka River estuarine area was marked by intense tectonic deformations along the coast of Kamchatsky Bay. The results show that suprasubduction and collision-related coastal deformations were often superimposed. For example, the Ust-Kamchatka fault is probably collision-related and extends far southward, intensely cutting the Holocene aggradation marine terrace in a suprasubduction zone. At the same time, the morphology of the terrace is a reflection of the coseismic and interseismic deformations during subduction earthquakes. This terrace, one of the largest aggradation terraces in Kamchatka, is about $3 \mathrm{ka}$ in age. Its older segment formed $\sim 3-6 \mathrm{ka}$ ago is not preserved. It seems likely that it has been eroded as a result of large-amplitude coseismic subsidence. This suggests that the northern edge of the subduction zone was capable of producing tsunamis and earthquakes as large as those generated along the eastern and southern segments of Kamchatka subduction zone. However, decisive testing of this hypothesis requires further study. The average recurrence interval for large tsunamis in Kamchatsky Bay comparable to the 1923 tsunami event is estimated at 300 years.

The deformations along the southern Kamchatsky coast and central part of the Kamchatsky peninsula occupied by Lakes Nerpichye and Kultuchnoye are largely associated with collision-related crustal short- ening. At the same time, these regions were periodically affected by coseismic deformation generated by subduction-zone earthquakes and related tsunamis. The major effects were variations in the hydrological regime and the salinity of Lakes Nerpichye and Kultuchnoye.

The new valley of the Kamchatka River was formed during the Holocene sea-level rise. A large body of shallow water formed in the area of the present Stolbovskaya lowlands was subsequently filled with sediments. Much of this former water body is now covered with peat deposits. The active crustal faults have had major effects on the surface morphology of the region, the groundwater level, the hydrological regime, and the peat accumulation rate.

The suprasubduction and collision-related deformations in the region differ in their character. Deformation related to subduction earthquakes is manifested as laterally extensive subsidence of various amplitudes along the entire coast. This deformation is not permanent and is mostly accommodated by rebuilding motion during the interseismic period. Conversely, the collision-related deformations are permanent and linear in character; they manifest themselves as strike-slip and thrust faulting.

\section{ACKNOWLEDGMENTS}

This study was supported by the Russian Foundation for Basic Research (project nos. 09-05-00125-a, 09-05-00286-a, 11-05-98534-r-vostok-a, 11-0500136-a, and 12-05-00712-a), the Far East Branch of the Russian Academy of Sciences (project no. 12-1P4-06), the United States National Science Foundation (project no. 0915131; principal researcher Ezra Zubrow). The authors also thank J. Bourgeois, E. Hulse, and D. Hillyer for their participation in the 2009 fieldwork at the Izvilisty Creek locality.

\section{REFERENCES}

1. A. A. Godzikovskaya, Catalogue of Macroseismic Descriptions of the Kamchatka Earthquakes during PreInstrumental Observation Period (18-19 centuries) (GS RAN, Obninsk, 2009) [in Russian].

2. E. I. Gordeev, A. A. Gusev, V. I. Levina, et al., "Crustal seismicity of Kamchatka," in Complex Seismological and Geophysical Studies. A Collection of Papers on 25th Anniversary of the Kamchatka Experimental-Methodical Seismological Party, GS RAN, Ed. by E. I. Gordeev and V. N. Chebrov (Petropavlovsk-Kamchatskii, 2004) [in Russian].

3. State Geological Map. $1: 200$ 000. Kamchatskaya PSE, Ed. by M. E. Boyarinova (Moscow, 1999) [in Russian].

4. A. A. Gusev, "Strong earthquakes of Kamchatka: location of focus during the instrumental period," Vulkanol. Seismol., No. 3, 39-42 (2006).

5. V. A. Ermakov, E. E. Milanovskii, and A. A. Tarakanovskii, "Significance of rifting in the formation of Quaternary volcanic zones of Kamchatka," Vestn. Mosk. Gos. Univ., No. 3, 3-20 (1974). 
6. Yu. Ya. Zayakin and A. A. Luchinina, Catalogue of tsunami on Kamchatka (VNIIGMIMTsD, Obninsk, 1987) [in Russian].

7. A. I. Kozhurin, V. V. Ponomareva, and T. K. Pinegina, "Active fault tectonics of the southern central Kamchatka," Vestn. KRAUNTs. Nauki O Zemle, No. 2, 10-27 (2008).

8. A. I. Kozhurin and T. K. Pinegina, "Active fault tectonics of teh Kamchatsky Peninsula as,amofestation of the collision between the Kamchatka and Aleutian island arcs," in Problems of seismotectonics: Proceedings of 16th International Conference, Moscow, Russia, 2011 (Moscow, 2011), pp. 260-263 [in Russian].

9. M. M. Pevzner, V. V. Ponomareva, and I. V. Melekestsev, "Chernyi Yar-the reference section of the Holocene ash markers in the northeastern Kamchtaka coast," Vulkanol. Seismol., No. 4, 3-18 (1997).

10. T. K. Pinegina, L. I. Bazanova, I. V. Melekestsev, et al., "Prehistoric tsunami on the Kronotsky Bay coast, Kamchatka, Russia,” Volcanol. Seismol., No. 2, 66-74 (2000).

11. T. K. Pinegina, E. A. Kravchunovskaya, A. V. Lander, et al., "Holocene vertical movements of the Kamchatsky Peninsula Coast from marine terrace data," Vestn. KRAUNTs. Nauki O Zemle, No. 1, 100-116 (2010).

12. T. K. Pinegina, A. I. Kozhurin, and V. V. Ponomareva, "Estimate of seismic and tsunami hazard for the Ust'Kamchatsk settlement (Kamchatka): evidence from paleoseismological data," Vestn. KRAUNTs. Nauki o Zemle, 19 (1), 138-159 (2012).

13. N. I. Seliverstov, Structure of the Near-Kamchatka Sea Bottom and Geodynamics of the Kuril-KamchatkaAleutian Junction Zone (Nauch. mir, Moscow, 1998) [in Russian].

14. N. I. Seliverstov, Geodynamics of Junction Zone of the Kuril-Kamchatka and Aleutian Island Arcs (KamGU im. Vitusa Beringa, Petropavlovsk-Kamchatskii, 2009) [in Russian].

15. F. Antomoli, E. Bard, E. Potter, et al., "215-ka history of sea-level oscillations from marine and continental layers in Argentarola Cave Speleothems (Italy)," Global Planet. Change 43, 57-78 (2004).

16. J. Bourgeois and V. V. Ponomareva, et al., "Holocene tsunamis in the southwestern Bering Sea, Russian Far East, and their tectonic implications," Geol. Soc. Am., Bull. 118 (3-4), 449-163 (2006).

17. J. Bourgeois and T. Pinegina, "Reconstructing the tsunamigemc earthquakes on the northern Kamchatka subduction zone: the 1997 Kronotsky earthquake and tsunamic and their predecessors," in 7-th Biennial Workshop on Japan-Kamchatka-Alaska Subduction Processes: Mitigating Risk through International Volcano, Earthquake, and Tsunami Science (JKASP-2011), Petropavlovsk-Kamchatsky, Russia, 2011 (IViS FEB RAS, Petropavlovsk-Kamchatsky, 2011), P. 197-198.

18. O. A. Braitseva, V. V. Ponomareva, L. D. Sulerzhitsky, et al., "Holocene Key-Marker Tephra Layers in Kamchatka, Russia," Quat. Res. 47, 125-139 (1997).

19. SAPB 6.0 program and documentation: http://calib. qub.ac.uk/ cahb.

20. C. DeMets, R. G. Gordon, D. F. Argus, et al., "Current plate motions," Geophys. J. Int. 101, 425-178 (1990).

21. B. C. Douglas, M. S. Kearney, and S. P. Teatherman, Sea Level Rise: History and Consequences (Acad. Press, San Diego, 2001).
22. R. Freitag, C. Gaedicke, B. Baranov, et al., "Collisional processes at the junction of the Aleutian-Kamchatka arcs: new evidence from fission track analysis and field observations," Terra Nova, No. 13, 433-142 (2001).

23. C. Gaedicke and N. Seliverstov, et al., "Structure of an active arc-continent collision area: the Aleutian-Kamchatka junction," Tectonophysics 325, 63-85 (2000).

24. E. L. Geist and D. W. Scholl, "Large-scale deformation related to the collision of the Aleutian arc with Kamchatka," Tectonics 13, 538-560 (1994).

25. A. Gorbatov, V. Kostoglodov, and G. Suarez, "Seismicity and structure of the Kamchatka subduction zone," J. Geophys. Res. 102, 898 (1997).

26. Global CMT catalog: http://www.globalcmt.org/CMTsearch. html

27. A. I. Kozhurin, "Active faulting at the Eurasian, North American and Pacific plates junction," Tectonophysics 380, 273-285 (2004).

28. A. I. Kozhurin, "Active faulting in the Kamchatsky Peninsula, Kamchatka-Aleutian Junction," in Volcanism and Subduction: The Kamchatka Region, Ed. by J. Eichelberger, E. Gordeev, M. Kasahara, et al., Amer. Geophys. Union, Geophys. Monogr. Ser. 172, 263282 (2007).

29. A. I. Kozhurin, "A Dangling slab and arc-normal extension: the case of Kamchatka, Russia," in Amer. Geophys. Union, Fall Meeting, San Francisco, US, 2009 (San Francisco, 2009).

30. J. P. McCalpin, Paleoseismology (Academic, London, 2009), Int. Geophys. Ser 95 (2009).

31. B. C. Papazachos, E. M. Scordilis, D. G. Panagiotopoulos, et al., "Global Relations Between Seismic Fault Parameters and Moment Magnitude of Earthquakes," Bull. Geol. Soc. Greece 36, 1482-1489 (2004).

32. J. Park, V. Levin, M. Brandon, et al., "A Dangling slab, amplified arc volcanism, mantle flow and seismic anisotropy in the Kamchatka plate corner," in Plate Boundary Zones, Ed. by S. Stein and J. Freymuller (Am. Geophys. Union. Washington, 2002), Geodynam. Ser., 30, 295-324 (2002).

33. K. Pedoja, J. Bourgeois, E. Pinegina, et al., "Does Kamchatka belong to North America? An extruding Okhotsk block suggested by coastal neotectonics of the Ozernoi Peninsula, Kamchatka, Russia,” Geololgy 34 (5), 353-356 (2006).

34. T. K. Pinegina and J. Bourgeois, "Historical and paleotsunami deposits on Kamchatka, Russia: long-term chronologies and long-distance correlations," Natural Hazards and Earth System Sciences 1 (4), 177-185 (2001).

35. T. Pinegina, J. Bourgeois, L. Bazanova, et al., "Millennial-scale record of Holocene tsunamis on the Kronotskiy Bay coast, Kamchatka, Russia," Quat. Res. 59, 36-47 (2003).

36. M. Stuiver and P. J. Reimer, "Extended ${ }^{14} \mathrm{C}$ database and revised CALIB radiocarbon calibration program," Radiocarbon 35, 215-230 (1993).

37. D. L. Wells and K. J. Coppersmith, "New empirical relationships among magnitude, rupture length, rupture width, rupture area, and surface displacement," Seismol. Soc. Am., Bull. 84 (4), 974-1002 (1994).

38. Worldwide Tsunami Database, 2000 B.C. to present. Boulder, Colorado, NOAA/NGDC. http://www.ngdc. noaa.gov/seg/hazard/tsudb.html)

Recommended for publishing by A.V. Koloskov Translated by N. Kravets 